\title{
An owlfly larva preserved in Mexican amber and the Miocene record of lacewing larvae
}

\author{
Una larva de mosca búho preservada en ámbar mexicano y el registro miocénico de \\ larvas neurópteros
}

\author{
Carolin Haug $^{1,2 *}$, Gideon T. Haug ${ }^{1}$, Viktor A. Baranov ${ }^{1}$, Mónica M. Solórzano-Kraemer ${ }^{3}$, \\ Joachim T. Haug ${ }^{1,2}$
}

${ }^{1}$ LMU Munich, Department of Biology II, Großhaderner Straße 2, 82152 Planegg-Martinsried, Germany.

${ }^{2}$ LMU Munich, GeoBio-Center, Richard-Wagner-Str. 10, 80333 München, Germany.

${ }^{3}$ Senckenberg Research Institute, Senckenberganlage 25, 60325 Frankfurt am Main, Germany.

* Corresponding author: (C. Haug)

carolin.haug@palaeo-evo-devo.info

\begin{abstract}
Neuroptera (lacewings) is today a rather small lineage of Holometabola. These representatives of Insecta have mostly predatory larvae with prominent venom-injecting stylets formed by upper and lower jaws. These impressive larvae can be found not only in the modern fauna, but sometimes also as fossils, predominantly preserved in amber. Here we report a new specimen of a lacewing larva from Miocene Mexican amber, most likely a larva of an owlfly (Ascalaphidae) with large prominent stylets, each with three teeth. These stylets arise from a more or less square-shaped head (in dorsal view) that has distinct eye hills with at least three simple eyes (stemmata) each. The trunk is rather short. Trunk segments possess finger-like protrusions carrying numerous setae, which could have been used to attach camouflaging debris to it. Remarkably, the specimen represents only the second report of a lacewing from Miocene Mexican amber, and the first larva. Additionally, we review the Miocene record of lacewing larvae. It includes otherwise only fossils preserved in Dominican amber and remains rather scarce, with only eight specimens in the literature so far. While there seem to be additional specimens in private collections, the overall number is astonishingly low compared to the numbers in Eocene and Cretaceous ambers. Ecological and taphonomic factors possibly explaining the rarity of lacewing larvae in Miocene amber are discussed here.
\end{abstract}

\section{Keywords: Ascalaphidae,} Myrmeleontiformia, Neuroptera, Mexico, Neogene.

\section{RESUMEN}

Neuróptera (crisopas) es hoy en día un linaje bastante pequeño entre los insectos holometábolos. Estos representantes de Insecta, con larvas que son principalmente depredadoras, tienen prominentes estiletes formados por las mandíbulas superior e inferior que inyectan veneno. Estas impresionantes larvas no solo se pueden encontrar en la fauna moderna, sino a veces también como fósiles, mayoritariamente preservados en ámbar. Aqui presentamos un nuevo espécimen de una larva de crisopa preservada en ámbar mexicano del Mioceno, que es muy probablemente una larva de Ascalaphidae (a veces también denominadas "moscas búho") con grandes y prominentes estiletes, cada uno con tres dientes. Estos estiletes provienen de una cabeza de forma más o menos cuadrada (en vista dorsal) con colinas visibles que presentan al menos tres ojos simples (stemmata) cada una. El tronco es más bien corto. Los segmentos del tronco poseen protuberancias en forma de dedos con numerosas setas que podrían haber sido utilizadas para acumular escombros para su camuflaje. Notablemente, este espécimen representa únicamente el segundo reporte de una crisopa en ámbar mexicano del Mioceno y la primera larva. Además, revisamos el registro del Mioceno de larvas de crisopa, que únicamente incluye fósiles preservados en ámbar dominicano y que sigue siendo bastante escaso, con solo ocho especímenes mencionados en la literatura hasta ahora. Si bien parece haber especimenes adicionales en colecciones privadas, el número total es sorprendentemente bajo en comparación con la cantidad de ejemplares en ámbar del Eoceno y del Cretácico. Los factores ecológicos y tafonómicos, que posiblemente expliquen la rareza de las larvas de crisopa en el ámbar del Mioceno, son también aquí discutidos.

Palabras clave: Ascalaphidae, Myrmeleontiformia, Neuróptera, México, Neógeno. 


\section{Introduction}

Neuroptera, the group of lacewings, is characterised by a rather unique type of larva. Lacewing larvae are generally fierce ambush predators. While adult lacewings resemble certain butterflies or dragonflies, lacewing larvae are quite special in their morphology. Their mouthparts are strongly forward directed (prognath) and very prominent. Each mandible, or upper jaw, is interlocked with one of the maxillae, lower jaws, to form a stylet, a combined venom-injecting and sucking tool. This pair of stylets can reach a large size and represent up to one third of the entire length of the larva in some lacewing ingroups. The maxillae lack distal parts, or palps. The labium, or lower lip, is deeply integrated into the head capsule and is mainly recognisable by its distal parts, the palps (MacLeod 1964; Gepp 1984; Aspöck and Aspöck 1999, 2007).

The most prominent examples of lacewing larvae are possibly those of antlions, which catch their prey in many cases with trap funnels burrowed in sandy ground (Badano, 2012). Another well-known fraction of lacewing larvae is that of aphid lions, the larvae of the groups Chrysopidae (green lacewings) and Hemerobiidae (brown lacewings). They are, as the name suggests, specialised on feeding aphids (e.g. Tauber et al., 2003). As the latter are severe plant pests, aphid lions have been successfully introduced as pest control some years ago, also due to their effectiveness and ecological benefits (Tauber et al., 2000).

Neuroptera is generally considered an early-appearing lineage of Holometabola (Grimaldi and Engel, 2005, p. 335), the ingroup of Insecta with immature forms addressed as 'larvae' due to their highly specialised eyes (for more information, see discussion in Haug, 2020). As compression fossils, lacewings have been commonly found as adults, whose wings seem to have a high potential of preservation (e.g. Makarkin, 2018). The fossil record of lacewing larvae is much scarcer and is largely restricted to fossil resins. The amber fossil record was recently summarised by Pérez-de la Fuente et al., (2020) and remains growing (e.g. Haug et al., 2019a, 2019b, 2020a, 2020b). The only two occurrences from compression fossils include a single specimen from the Cretaceous Crato formation (Martins-Neto et al., 2007; Herrera-Flórez et al., 2020, including a discussion about another presumed specimen) and a single specimen from the Eocene Green River formation (Dayvault et al., 1995).

Ambers that have so far yielded lacewing larvae have provided quite a number of specimens, especially Cretaceous ambers: at least 11 specimens originated from Cretaceous Lebanese amber (Whalley, 1980; Pérez-de la Fuente et al., 2018, 2019), four specimens from Cretaceous Spanish amber (Pérez-de la Fuente, 2012, 2016, 2020), three specimens from Cretaceous French amber (Perrichot, 2003; Perrichot et al., 2010; Wang et al., 2016), a single specimen from Cretaceous Canadian amber (Engel and Grimaldi, 2008) and a single specimen from New Jersey amber (Grimaldi, 2000, p. 284, fig. 3). Amber from Myanmar (also known as "Burmese amber"; for a recent discussion of the political background of this amber, see Haug et al., 2020c) yielded an astonishing amount of lacewing larvae (Xia et al., 2015; Wang et al., 2016; Liu et al., 2016, 2018; Wichard 2017; Zhang 2017; Badano et al., 2018; Lu et al., 2018; Makarkin, 2018; Haug et al., 2018, 2019a,2019b,2019c, 2020a, 2020b).

Especially these findings from the Cretaceous indicate an enormous diversity of larval forms of lacewings more than 100 million years ago compared to the modern fauna. On that regard, it is interesting to compare the diversity of larval forms with the younger ambers to better understand when the diversity of lacewing larvae could have declined. However, comparisons must be treated carefully, since ecological bias has to be taken into account (Solórzano-Kraemer et al., 2015, 2018). The resin-producing trees during the Cretaceous and Eocene are representatives of the group Coniferopsida (gymnosperms), while during the Miocene resin-producing trees are representatives of the group Magnoliopsida (angiosperms; Seyful- 
lah et al., 2018), thus faunal assemblages inhabiting the trees could be different (e.g. Peris et al., 2017a).

Eocene Baltic amber has provided quite a number of larval lacewing specimens (Weidner, 1958; MacLeod, 1970; Larsson, 1978; Janzen, 2002; Weitschat and Wichard, 2002; Scheven, 2004; Weitschat, 2009; Wichard et al., 2009; Ohl, 2011; Makarkin et al., 2012; Wunderlich, 2012; Wedmann et al., 2013; Gröhn, 2015; Pérez-de la Fuente et al., 2020; Haug et al., 2020a, 2020b). Yet, there are still significantly fewer findings than from amber from Myanmar. Moreover, other Eocene ambers have hitherto not yielded lacewing larvae.

Even scarcer is the record from Miocene ambers. So far only eight specimens have been reported from Miocene Dominican amber $(\mathrm{Wu}$, 1996; Poinar and Poinar, 1999; Grimaldi and Engel, 2005; Engel and Grimaldi, 2007). Dominican amber has been dated as early Middle Miocene (Iturralde-Vinent and MacPhee, 1996, 2019), whereas the age of Mexican amber from Chiapas is still in discussion; Solórzano-Kraemer, (2007) argued for a similar age to Dominican amber $(\sim 16$ Mya $)$ based on a correlation of foraminiferans, corals, decapodan crustaceans, mollusks, and pollen from different formations in Chiapas, Mexico, Hispaniola, and Puerto Rico. However, Serrano-Sánchez, et al. (2015) argued for an age of 22.8 million years based on the biostratigraphy of corals, mollusks, microfossils and strontium from one deposit, namely Campo La Granja mines, which belong to the La Quinta Formation. Ambers from Estrella de Belén deposit in the Salto de Agua Municipality, near Palenque, the origin of the amber described here, correspond also to those Miocene coarse quartz sands of the La Quinta Formation (Alvarado-Ortega et al., 2018). Both ambers, the Mexican and the Dominican ambers, come from similar environments, and the amber-producing tree in both instances belongs to species of the extant species group (genus) Hymenaea L. (Poinar, 1991; Poinar and Brown, 2002; Calvillo-Canadell et al., 2010).

Here we summarise the Miocene record of lacewing larvae from Dominican amber and report a new specimen from Miocene Mexican amber from the Estrella de Belén deposit.

\section{Material and methods}

\subsection{MATERIAL}

In the centre of this study is a single piece of amber from the Estrella de Belén deposit in the Salto de Agua Municipality, near to Palenque in Chiapas, Mexico. The specimen is stored in the amber collection at the Senckenberg Forschungsinstitut und Naturmuseum, Frankfurt am Main (SMF) under the accession number SMF Be 642a. Preserved inside the amber piece SMF Be 642, beside the lacewing larva, there are numerous syn-inclusions: one springtail (Collembola), six flies (Diptera: one of Psychodidae, four of Sciaridae, and one of Cecidomyiidae), one ant (Hymenoptera: Formicidae), one bark louse (Psocodea), as well as plant remains and quite some debris.

\subsection{DOGUMENTATION METHODS}

Documentation was performed on a Keyence VHX 6000 digital microscope. The specimen was documented from one side only, the other side was inaccessible. It was illuminated in two different ways, once by coaxial cross-polarised light (Haug et al., 2013a) and once by unpolarised ring light. Under both illuminations, documentation was performed with a white and a black background. The combination providing the best contrast was used to be presented here. The built-in HDR function was used to optimise the images (cf. Haug et al., 2013b). Image stacks were recorded to overcome limitations in depth of field; several adjacent stacks were recorded to overcome limitations in field of view (Haug et al., 2008, 2011).

\subsection{IMAGE PROGESSING}

Images recorded on the Keyence VHX 6000 digital microscope were processed automatically by 
the built-in software. Adobe Photoshop CS2 and CS3 were used for optimising all images (histograms, saturation, sharpness).

\subsection{PRESENTATION}

Visible structures of the fossil were colour-marked to provide an interpretation of the structures. Adobe Illustrator CS2 was used to redraw lacewing larvae from literature. The drawings were slightly simplified; same colours were assigned to corresponding structures.

\section{Results}

All occurrences of depictions of lacewing larvae in Miocene ambers are listed chronologically. Cases in which the same specimen has been re-figured are also included chronologically with reference to the original occurrence. While this includes a certain redundancy, it should represent the most complete way of cross-referencing, avoiding interpreting the same specimen as two independent occurrences.

1) Wu (1996) depicted a specimen of a lacewing larva preserved in Dominican amber (specimen 1; Figure 1A). The specimen (p. 136, fig. 224) is seen in dorso-lateral view; the body is slightly curled, but the head with the prominent stylets is well accessible. The author interpreted it as a larva of a brown lacewing (Hemerobiidae). Yet it remains unclear on which characters this interpretation is based. The overall appearance is in our view more compatible with an interpretation as a larva of a green lacewing (Chrysopidae).

2) Poinar and Poinar (1999) depicted two specimens of lacewing larvae preserved in Dominican amber. The first specimen (p. 86, fig. 94; figure plates between pp. 110, 111) was interpreted as the larva of an antlion (Myrmeleontidae). This specimen (specimen 2, Figure 1B) is well visible in ventral view. No indication of size was provided. The second specimen (figure plates between pp. 110,111 ; p. 129, fig. 128) was interpreted as the larva of an owlfly (Ascalaphidae). The body of this specimen (specimen 3; Figure 1G) is less well visible due to camouflage with debris, yet the large mandibles are well apparent. No indication of size was provided. Poinar and Poinar (1999) did not provide the necessary details for a more accurate description of the systematic position, and also did not provide any accession number. The overall information of these specimens is therefore limited.

3) Scheven (2004) depicted one specimen of a lacewing larva preserved in Dominican amber (p. 142). The specimen (specimen 4; Figure 1D) was stated to be $2 \mathrm{~mm}$ in total length. The specimen is accessible in dorsal view.

4) Grimaldi and Engel (2005) depicted three specimens of lacewing larvae preserved in Dominican amber. The first one is a larva of the group Myrmeleontidae (accession number Morone Collection, M1282). The specimen (specimen 5; Figure 1E) was interpreted as a possible representative of the group Porrerus Navas, 1913. Length was stated to be $4.5 \mathrm{~mm}$. A photomicrograph of the specimen shows that it is well preserved in clear amber, accessible in latero-dorsal view (Grimaldi and Engel 2005, p. 346, fig. 9.20). The second specimen is a representative of the group Ascalaphidae (accession number Morone Collection M3550). The specimen (specimen 6; Figure 2A) was interpreted as a representative of the group Ululodes Currie, 1900. Length was stated to be $8 \mathrm{~mm}$. A photomicrograph of the specimen shows that it is well accessible in ventral view (p. 38, fig. 9.24). The third one is a larva of the group Chrysopidae (AMNH without further number), hence an aphid lion (specimen 7; Figure 2B). Length was stated to be $1.3 \mathrm{~mm}$. A detailed drawing of the specimen shows that it is well preserved in latero-dorsal view, exhibiting short protrusions with long setae (p. 352, fig. 9.31). All three specimens have been re-figured in Engel and Grimaldi (2007).

5) Engel and Grimaldi (2007) depicted five specimens of lacewing larvae preserved in Dominican amber. The first one is a re-figure (p. 32, fig. 


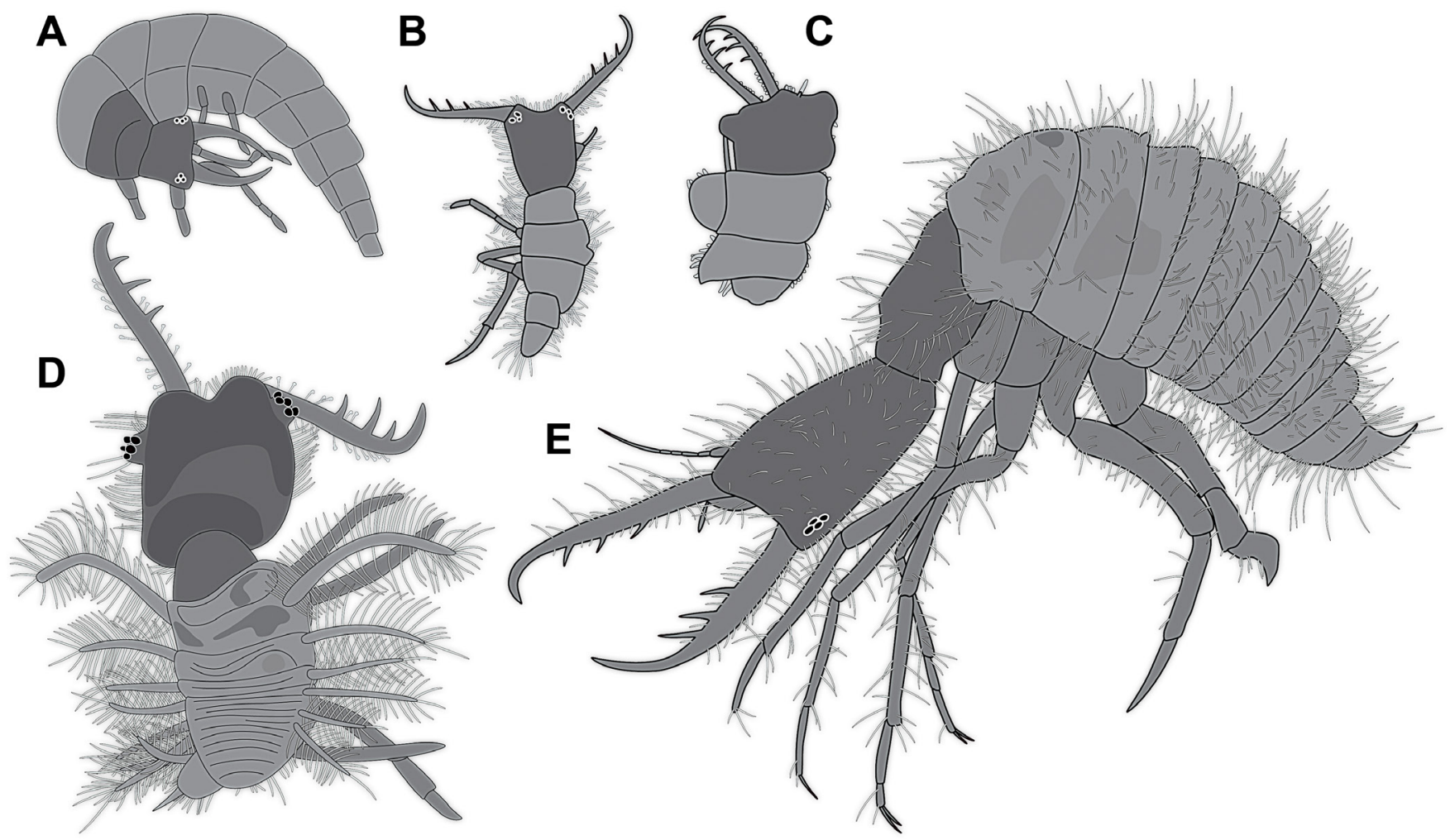

Figure 1 Lacewing larvae preserved in Miocene Dominican amber from the literature. All simplified interpretive drawings; similar grey values indicate corresponding structures. Not to scale, specimens with more available details depicted larger. A. Specimen 1 , aphid lion (Chrysopidae), based on Wu (1996, p. 136, fig. 224), size unknown. B, C. Based on Poinar and Poinar (1999), sizes unknown. B. Specimen 2 (p. 86, fig. 94 and figure plates between pp. 110, 111 ). C. Specimen 3 (figure plates between p. 110, 111; p. 129, fig. 128). D. Specimen 4, owlfly larva (Ascalaphidae), based on Scheven (2004, p. 142), size unknown. E. Specimen 5, antlion larva, possibly of Porrerus dominicanus Stange and Poinar. MACT-1282, based on Grimaldi and Engel (2005, p. 346, fig. 9.20; also Engel and Grimaldi 2007, p. 39, fig. 42 and p. 40, fig. 43), total size about $4.5 \mathrm{~mm}$.

34) of the drawing of specimen 7 , i.e. the aphid lion depicted in Grimaldi and Engel (2005). Here an accession number (DR-10-1454) was provided. The second one is a grey-scale version (p. 39, fig. 42) of the photomicrograph of specimen 5, the antlion larva depicted in Grimaldi and Engel (2005). Here accession number was given as MACT-1282. The specimen was interpreted as a possible representative of the species Porrerus dominicanus Stange and Poinar, 1996. Additionally an interpretive drawing (p. 40, fig. 43) was provided. The third specimen is a larva of the group Ascalaphidae (accession number MACT-1200). The specimen (specimen 8; Figure 2C) was interpreted as a representative of the group Ululodes, of a distinct species sp. 1. A photomicrograph (p. 45, fig. 47) and interpretive drawings of the habitus and the head (p. 46, fig.
48) were provided. Body length was stated to be about $5.9 \mathrm{~mm}$ (p. 44). The fourth specimen is also a representative of the group Ascalaphidae (accession number AMNH DR-10-2010). The specimen (specimen 9; Figure 2D) was interpreted as a representative of the group Ululodes and also of the distinct species sp. 1. An interpretive drawing of the head was provided (p. 47, fig. 49). Length of the head capsule was stated to be $1.5 \mathrm{~mm}$. The fifth one is a grey-scale version (p. 49, fig. 50) of the photomicrograph of specimen 6 , the owlfly larva depicted in Grimaldi and Engel (2005). Here accession number was given as MACT-3550. The specimen (specimen 6; Figure 2A) was interpreted as a representative of the group Ululodes and of the distinct species sp. 2. Additionally, an interpretive drawing of the head (p. 50, fig. 51) was provided. 

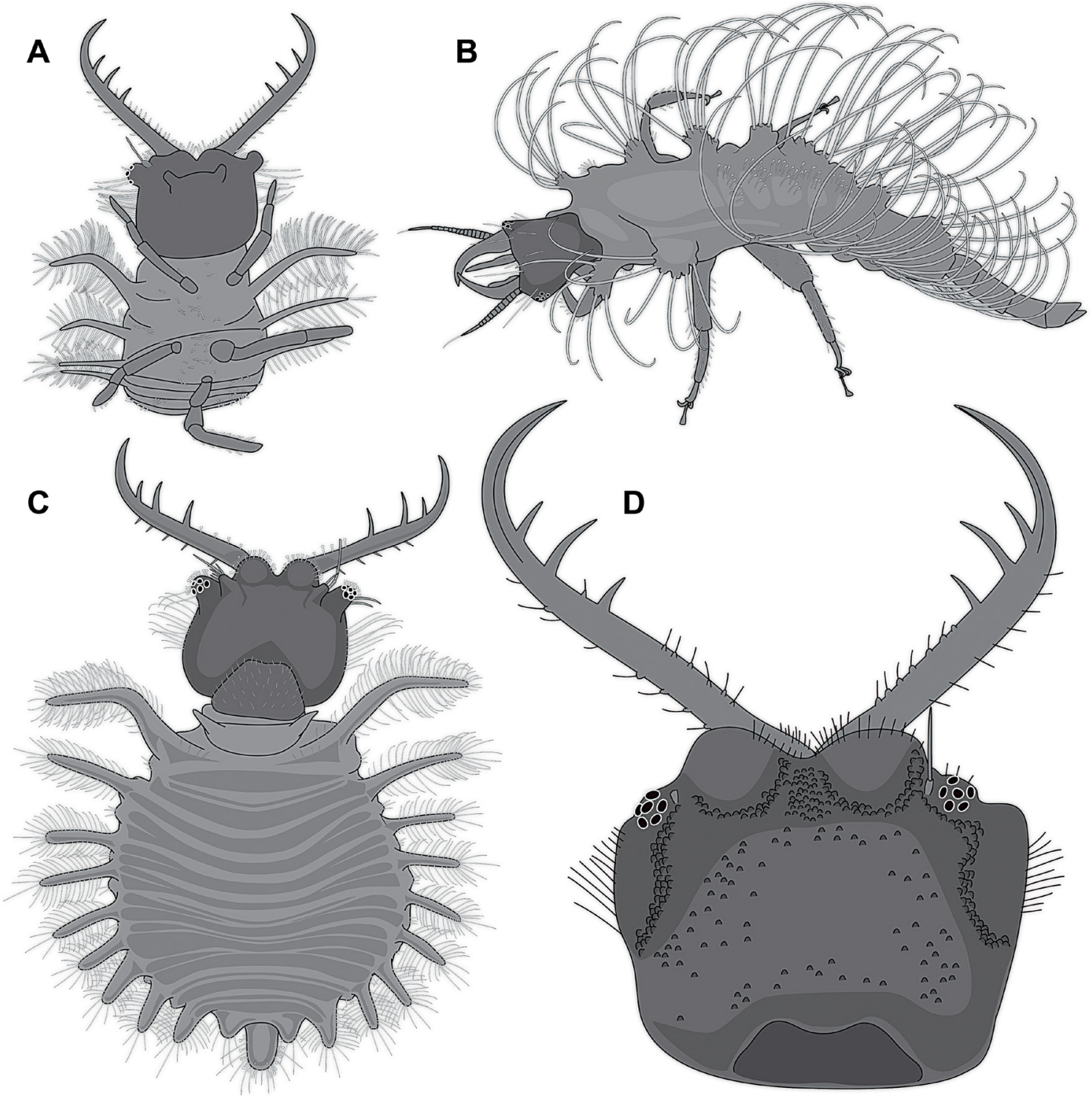

Figure 2 Lacewing larvae preserved in Miocene Dominican amber from the literature, continued. All simplified interpretive drawings; similar grey values indicate corresponding structures. Not to scale, specimens with more available details depicted larger. $A$, $B$. Based on Grimaldi and Engel (2005). A. Specimen 6 (p. 38, fig. 9.24; also Engel and Grimaldi 2007, p. 49, fig. 50), owlfly larva (Ascalaphidae), Ululodes sp. 2, MACT-3550, total size about $8 \mathrm{~mm}$. B. Specimen 7 (p. 352, fig. 9.31; also Engel and Grimaldi 2007, p. 32, fig. 34), aphid lion (Chrysopidae), DR-10-1454, total size about $1.3 \mathrm{~mm}$. C, D. Based on Engel and Grimaldi (2007). C. Specimen 8 (p. 45 , fig. 47 and p. 46, fig. 48), owlfly larva (Ascalaphidae), Ululodes sp. 1, MACT-1200, body length about $5.9 \mathrm{~mm}$. D. Specimen 9 (p. 47, fig. 49), owlfly larva (Ascalaphidae), Ululodes sp. 1, AMNH DR-10-2010, head capsule length about $1.5 \mathrm{~mm}$.

6) Given the scarceness of data on lacewing larvae in Miocene amber, we used certain online resources as additional data sources (see discussion of use of websites as scientific source in Haug and Haug 2019; Haug et al. 2020a). In order to make these images available, we asked the copyright holders whether we could depict their images in this contribution. In total, we present images of six such specimens, all are preserved in Dominican amber. The first of these specimens is the larva of an owlfly (Ascalphidae). The image (Figure 3A) was kindly provided by TerraTreasures and Adventures 101 (terratreasures.com). Size of the specimen is unclear. The second of these specimens 
is the larva of an antlion (Myrmeleontidae). The image (Figure 3B) was kindly provided by Huang Yi-Jen (amber boy, huangyijen0708). Size of the specimen is unclear. Images of the third to sixth specimen were kindly provided by GlobalNaturalResources. The third specimen (Figure 3G) is the larva of an antlion (Myrmeleontidae). It is slightly less than $3 \mathrm{~mm}$ long. The fourth specimen (Figure 3D) is the larva of an owlfly (Ascalaphidae). It is slightly longer than $4 \mathrm{~mm}$. The fifth specimen (Figure $3 \mathrm{E}$ ) is also a larva of an owlfly (Ascalaphidae).
It is slightly less than $3 \mathrm{~mm}$ long. This image is also available in the online repository iStock by Getty Images (istockphoto.com). The sixth specimen (Figure 3F) is an aphid lion (Chrysopidae). It is about $4 \mathrm{~mm}$ long. These six specimens are not available for further detailed study, only the images are available. Due to the distinct scarcity of Miocene lacewing larvae, specimens found in different internet sources contribute to certain valuable information about the diversity that remains still to be discovered.

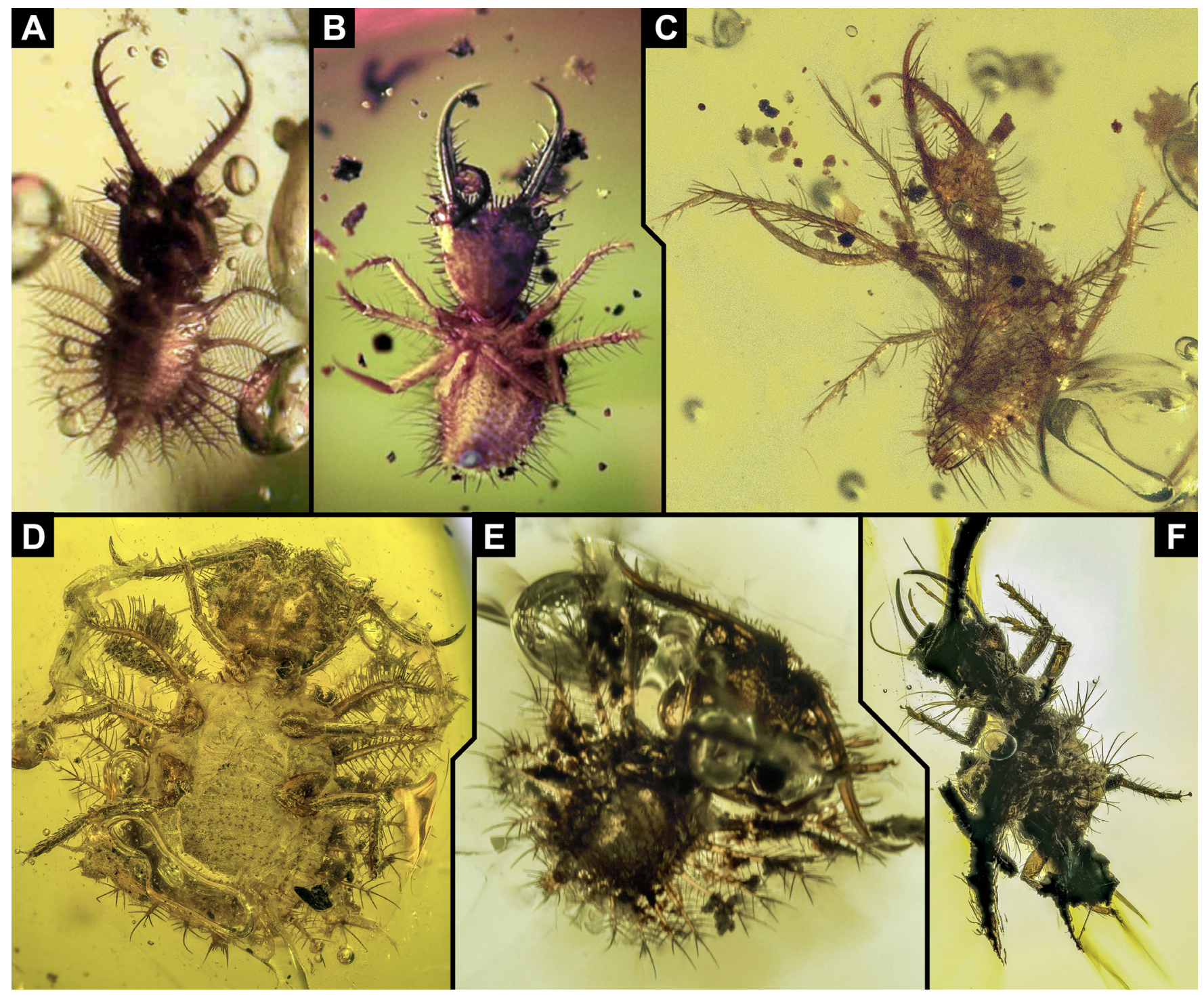

Figure 3 Images of additional specimens of lacewing larvae preserved in Miocene Dominican amber. A. Owlfly; image from TerraTreasures and Adventures 101 (terratreasures.com). B. Antlion; image from Huang Yi-Jen (amber boy, huangyijen0708). $C-F$. Images from GlobalNaturalResources. C. Antlion. D, E. Owlfly. F. Aphid lion. Not to scale. 
7) A new fossil specimen of a presumed owlfly larva (Ascalaphidae) is reported here (Figures 4A, $4 \mathrm{~B}$, and 5). The specimen originates from Mexican amber from Estrella de Belén deposit in the Salto de Agua Municipality, near Palenque in Chiapas, Mexico, and is part of the amber collection of the Senckenberg Forschungsinstitut und Naturmuseum, Frankfurt am Main (accession number SMF Be 642a). The amber piece is rather large and thick.
Description: The larva is visible in dorsal view. Body is organised into (presumably) $20 \mathrm{seg}$ ments (ocular segment +19 post-ocular segments) and differentiated into head and trunk.

Head: formed by ocular segment and post-ocular segments 1-5. Head with distinct head capsule. Head capsule and protruding structures longer than trunk. Head capsule roughly squareshaped in dorsal view. Lateral rims with numerous prominent setae. Ocular segment recognisable

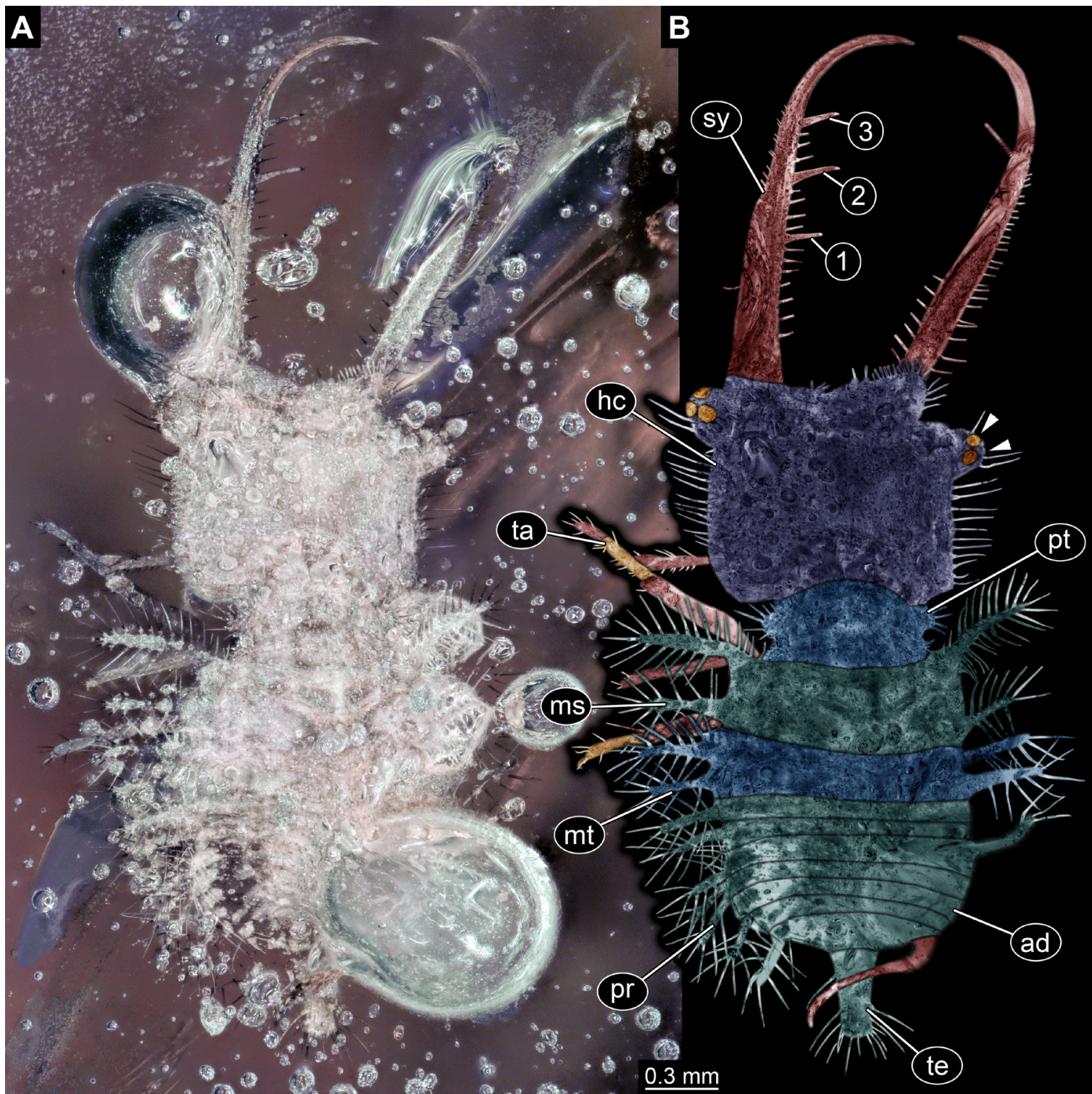

Figure 4 New owlfly larva from Miocene Chiapas amber, specimen SMF Be 642a. A. Composite image, black background, unpolarised ring light. $B$. Colour-marked interpretation of structures, arrowheads indicate stemmata. Abbreviations: $1-3=$ teeth on stylet; ad $=$ abdomen (posterior trunk); $h c=$ head capsule; $m s=$ mesothorax; $m t=$ metathorax; $p r=$ process or protrusion; $p t=$ prothorax; $s y=$ stylet (compound structure formed by mandible and maxilla); $t a=$ trunk appendage ("leg"); $t e=$ trunk end. 
by a pair of groups of simple eyes. Each group with at least three simple eyes (stemmata). Groups antero-laterally on head capsule, on distinct protrusions ("eye hills"). No external structures of post-ocular segments 1 and 2 apparent. Appendages of post-ocular segments 3 and 4 presumably forming compound structures (stylets), yet only appendages of post-ocular segment 3 accessible, mandibles. Mandibles large, almost 1.5 times as long as head capsule, protruding forward (prognath). They are curved in the distal region, the tip is facing inwards. Three prominent teeth are pres-

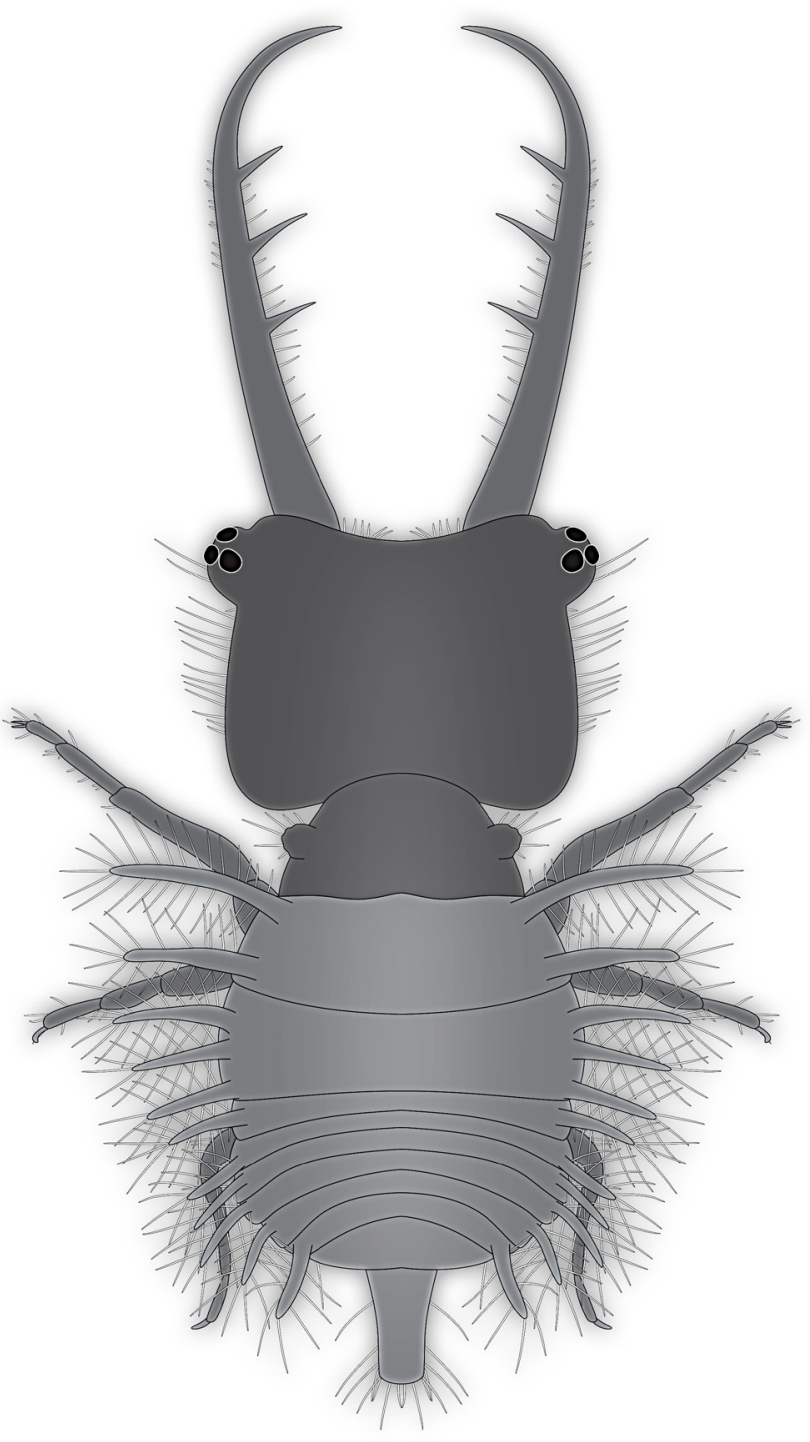

Figure 5 Simplified restoration of the new owlfly larva from Miocene Chiapas amber, based on specimen SMF Be 642a. ent along the inside of the mandible. Additionally numerous setae are present on the inner and outer edge of the mandible.

Trunk: longer than wide. Anterior three segments (thorax) larger than further posterior ones (abdomen). Trunk segment 1 (prothorax; post-ocular segment 6) narrower than head. With a smaller protrusion on each side, bearing numerous setae. Trunk segment 2 (mesothorax; post-ocular segment 7) about as wide as the head. With two finger-like protrusions on each side. Each protrusion with numerous long setae. Trunk segment 3 (metathorax; post-ocular segment 8) sub-similar to preceding segment. Protrusions slightly shorter. Trunk segments 4-10 (abdomen segments 1-7; post-ocular segments 9-15) sub-similar. Shorter than preceding segments. Progressively narrower towards the posterior. Each segment with a finger-like protrusion on each side. Each protrusion with numerous long setae. Trunk segment 11 (abdomen segment 8; post-ocular segment 16) slightly longer than preceding segments, strongly narrowing towards the posterior. With a finger-like protrusion on each side. Each protrusion with numerous long setae. Trunk end (most likely representing undifferentiated abdomen segments 9-11; post-ocular segments 17-19) slender, longer than wide. With numerous long setae along the posterior end. More distal regions or trunk appendages (legs) are apparent. Details remain largely unclear, subdivision only partly apparent.

\section{Discussion}

\subsection{IDENTITY OF THE SPECIMEN}

The overall shape and especially the mandible morphology allow to identify the specimen as a larva of Neuroptera and of Myrmeleontiformia (the group with all antlion-like lacewings). Three prominent teeth are in the modern fauna only found in larvae of antlions (Myrmeleontidae) and owlflies (Ascalaphidae). Yet, three teeth have also been present in other representatives of Myrmeleontiformia (Haug et al., 2019c). 
Myrmeleontidae and Ascalaphidae share the presence of a tibio-tarsus ("fusion") on trunk appendage 3 (metathorax leg). In the fossil described here it remains partly unclear whether there is a tibio-tarsus, this region of the appendage it is not well visible, but partly concealed under a bubble. Also, other features characterising the group Myrmeleontidae + Ascalaphidae (as put forward by Badano et al. 2017, p. 100) are not visible. Still the overall morphology makes it most likely that the specimen is the larva of a species of Ascalaphidae. In any case, this represents the second report of a lacewing from Mexican amber (the other one is an adult mantis lacewing, Mantispidae; Engel and Grimaldi 2007; p. 10-13, figs. 4-8), the first report of a lacewing larva from this amber, and possibly the first report of an owlfly (Ascalaphidae).

\subsection{THE AMBER REGORD OF LAGEWING LARVAE: GRETAGEOUS AMBER}

Amber has fascinated various scientists, especially entomologists. Ambers from deep geological time have been considered as especially important because they provide data on the ecology of forest ecosystems millions of years old and on the evolutionary history of organisms and their behaviour which are otherwise rarely preserved in the fossil record. On that regard, finding the oldest fossil of a specific group is quite significant.

Triassic ambers have so far only yielded one representative of Insecta, a midge (Diptera), and two species of eriophyoidean mites (Schmidt et al., 2012). Therefore, the insect-rich Cretaceous ambers have been given quite some attention. This is also true for lacewing larvae. Lacewing larvae from the Lebanon represent the oldest such larvae (Pérez-de la Fuente et al., 2018, 2019). Younger Cretaceous ambers from New Jersey, Canada, Spain, France and Myanmar have yielded an astonishing diversity of lacewing larvae. Some of these larvae resemble modern forms, but others represent astonishingly different, aberrant-appearing forms. Myanmar amber is unparalleled concerning the output of lacewing larvae (Wang et al., 2016: about 30 specimens; mostly single specimens in Liu et al.,
2016, 2018; Makarkin, 2018; Haug et al., 2019a, 2019b, 2019c, 2020a, 2020b; see also Pérez-de la Fuente et al., 2020). It appears that overall clearly more than 200 specimens are currently available in different Cretaceous amber collections. Given numerous additional specimens offered via internet by various amber traders, this seems to be only the tip of the iceberg.

\subsection{THE AMBER REGORD OF LAGEWING LARVAE: BALTIC AMBER}

Younger ambers from the Eocene, especially Baltic amber, have likewise yielded lacewing larvae. For some lineages, Baltic amber provides the oldest record, as for example Sisyridae (at least two specimens; Wichard et al., 2009) and Coniopterygidae (at least one specimen so far; Weitschat and Wichard, 1998, 2002; more seem to be present). For some other lineages the Eocene record is more extensive concerning numbers of specimens than for the Cretaceous amber, as for example Nevrorthidae (at least 20 specimens so far; Haug et al., 2020b; seen more in the possession of traders). Further finds include larvae of Mantispidae (one specimen; Ohl, 2011), Berothidae (at least five specimens; Wedmann et al., 2013), Chrysopidae (three specimens: Scheven, 2004, p. 68, 69; Weitschat, 2009, p. 254, fig. 45). Hemerobiidae (one specimen; Makarkin et al., 2012), Ascalaphidae (at least two specimens; MacLeod, 1970; Weitschat and Wichard, 2002), Nymphidae (one specimen; MacLeod, 1970), Psychopsidae (at least twelve specimens; Haug et al., 2020a) and also some specimens that are clearly larvae of Neuroptera, but the exact affinity remains unclear (e.g. Larsson, 1978, see discussion in Haug et al., 2020a). In total, there are (at least) about 50 specimens of lacewing larvae preserved in Baltic amber. This number is strongly influenced by Nevrorthidae (especially one piece with seven larval specimens; Wichard et al., 2009, p. 113, fig. 07.19a) and Psychopsidae (silky lacewings), still this is a quite higher number compared to the Miocene record. 


\subsection{WHY IS THE NUMBER OF LACEWING LARVAE LOWER FOR THE MIOGENE RECORD?}

The fossil record available in the literature and in the internet shows an apparent decrease in the presence of lacewing larvae in amber forests from the Cretaceous to younger fossil deposits. The Eocene record of lacewing larvae is less extensive than the Cretaceous one. The Miocene is even less extensive. Besides the specimen reported here, the Miocene record was so far restricted to specimens preserved in Dominican amber. However, Miocene amber deposits with bioinclusions, besides the Mexican amber, are known from Ethiopia (Bouju and Perrichot, 2020), from China (Shi et al., 2014), from Peru (Antoine et al., 2006), and from New Zealand (Schmidt et al., 2018), all discovered relatively recent so that the amount of amber with inclusions is still small. In younger copal or Defaunation resin (sensu Solórzano-Kraemer et al., 2020), only one case of a lacewing larva is known from Colombian copal or Defaunation resin (age unknown) (Kobbert, 2013, p. 55, fig. 206). Adults of the group Coniopterygidae have been described from copal or Defaunation resin of unknown age from Madagascar and the African mainland (Engel, 2004), a group also reported in Miocene Dominican amber and in Eocene Cambay amber (Grimaldi et al., 2013). Dominican amber has been considered to be a "highly fossiliferous" amber (e.g. Arillo and Ortuño, 2005; Penney, 2016); in the light of this view, it is somehow surprising that there are so few specimens of lacewing larvae.

The simple numbers give a pattern that shows a decrease of available lacewing larvae over time: The highest number is available for the Cretaceous, the number is lower in the Eocene, and finally lowest in the Miocene (Figure 6). In how far could this represent a true pattern and not a sampling or ecological bias? The Cretaceous offers several ambers with a wide geographic coverage (yet this is also the case for Miocene and Eocene ambers) including North America (Canadian amber), Europe (French and Spanish amber) and Asia (Lebanon, Myanmar). Especially Myanmar amber has provided a high output of overall specimens due to several factors (Haug et al., 2020c).
It may therefore not be surprising that so many new lacewing larvae have been reported from Myanmar amber (Engel and Grimaldi, 2008; Xia et al., 2015; Wang et al., 2016; Liu et al., 2016, 2018; Zhang, 2017; Badano et al., 2018; Haug et al., 2018, 2019a, 2019b, 2019c, 2020a, 2020b; Herrera-Flórez et al., 2020). Yet, the other Cretaceous ambers have also provided quite a number of significant specimens (Engel and Grimaldi, 2008; Pérez-de la Fuente, 2012, 2016, 2018, 2019, 2020; Haug et al., 2020a). The resin-producing trees, which later generated the Cretaceous ambers, were representatives of Coniferopsida (gymnosperms), mostly of the ingroup Araucariaceae but also of the ingroups Cupressaceae, Cheirolepidiaceae or Pinaceae (Seyfullah et al., 2018).

The Eocene Baltic amber has a long research tradition. Hence it should not be surprising that there are quite some lacewing larvae known from Baltic amber. The resin-producing tree of the Eocene Baltic amber was also a representative of the group Coniferopsida of the ingroup Pinaceae or Sciadopityaceae (Wolfe et al., 2016). Yet, if we look closer, the relatively high number of larvae is mostly due to specific lineages within lacewings, Psychopsidae and Nevrorthidae (see above). Larvae of other groups are quite rare, as there is, for example, only a single larva of Nymphidae known (MacLeod, 1970). We might speculate that larvae of Nevrorthidae and Psychopsidae became trapped in resin more easily than other lacewing larvae.

Today Nevrorthidae and Psychopsidae show quite restricted ranges of occurrence that makes it more unlikely to find them in Miocene American ambers. Representatives of Nevrorthidae nowadays occur in Mediterranean Europe, China, Japan and Australia (Aspöck and Aspöck, 2010). Representatives of Psychopsidae occur today in SouthEast Asia, southern Africa and Australia (Peng et al., 2011). There are several examples of groups, that nowadays have representatives restricted to Australasia, but which have fossil forms preserved in Dominican amber, in total 18 species groups (genera); this includes lacewings of the ingroup Aleuropteryginae (Grimaldi et al., 2013). Still, we 


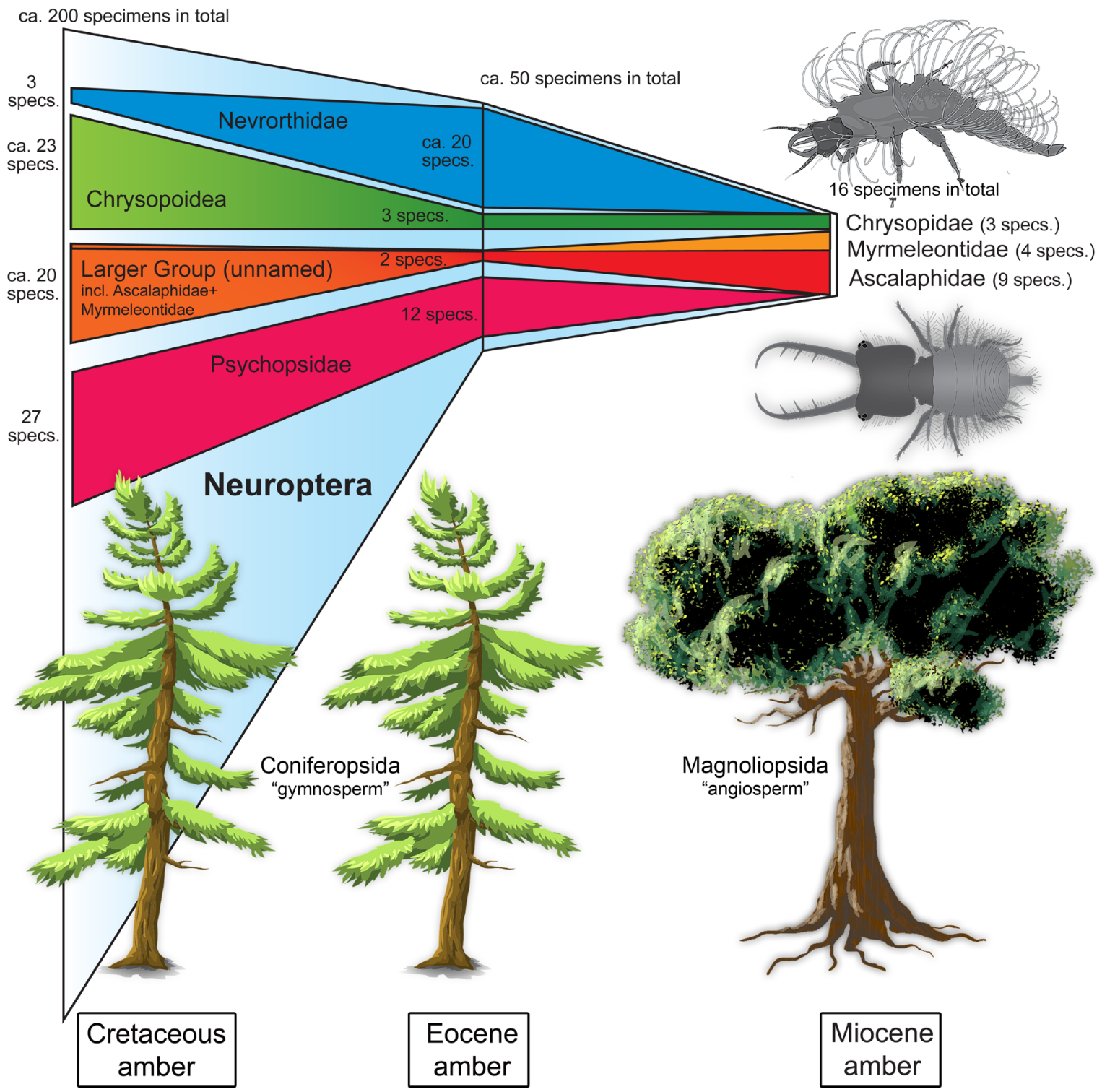

Figure 6 Depiction of number of larval lacewing specimens preserved in amber per time slice. Numbers given for the entire group of Neuroptera, as well as for some ingroups: Nevrorthidae, Psychopsidae (silky lacewings), Chrysopoidea (including its ingroup Chrysopidae; green lacewings, aphid lions; upper right image) and a larger unnamed group including Myrmeleontidae (antlions) and Ascalaphidae (owlflies; lower right image). The different sources of amber are indicated by schematic representatives of the groups Coniferopsida ("gymnosperms") and Magnoliopsida ("angiosperms"). Note the dominance of the groups Psychopsidae and Nevrorthidae in the Eocene.

cannot expect to find larvae of Psychopsidae and Nevrorthidae, but we can also not fully exclude it. The occurrence of representatives of Nevrorthidae in Dominican amber is furthermore unlikely as the deposit is notoriously poor concerning representatives of merolimnic groups of Insecta, i.e. those with aquatic larvae (Grund, 2006). The absence of these two lineages might, in any case, be part of the effect that the number of known lacewing larvae from this amber is rather low.

The high number of larvae from Cretaceous ambers may not be easily explained by sampling bias. An ecological bias of lacewings in general was discussed by Engel and Grimaldi (2007) relating their abundance and diversity in ambers to the abundance of sternorrhynchan hemipterans. 
The latter are rare in Miocene ambers. Actuo-taphonomic studies also support the low abundance of lacewings (larvae and adults, however within the low abundance there are more adults than larvae) and sternorrhynchan hemipterans in modern-day resin and sticky traps in Hymenaea-type forests (ingroup of Magnoliopsida, "angiosperm") in Mexico and in Madagascar (Solórzano-Kraemer et al., 2015, 2018). Notably, in the sticky traps in the Hymenaea-type forest in Mexico, where sternorrhynchans were lightly abundant (89 specimens), five lacewings (four larvae and one adult) were collected (Solórzano-Kraemer et al., 2015). In Malagasy resin collected in 2013, only one adult of the group Neuroptera $(0.02 \%)$ has been recognized from 3,923 representatives of Euarthropoda (Solórzano-Kraemer et al., 2018). On the contrary, in modern resins originating from species of Pinus L. and Picea A. Dietr, 1824 (both ingroups of Coniferopsida, "gymnosperms") collected by Zherikhin et al., (2009) in Northern Eurasia lacewings were more common, from 0.3 to $3.7 \%$ in the different samples.

However, it has to be noticed that these data are not specific of larvae. Pérez-de la Fuente $e t$ al., (2020) related the scarcity of antlion larvae (Myrmeleontidae) in amber to their soil-dwelling lifestyles. This implies resin production at soil level or the drip of the resin in the soil to preserve this kind of organism. The antlion larvae seem to be more frequent in Miocene amber than in Cretaceous or Eocene ambers.

It is well known that the more active organisms living in or in closer relation to the resin-producing tree have a higher probability to become entombed in resin and therefore preserved in amber (Solórzano-Kraemer et al., 2018). Miocene ambers were produced by trees of the groups Fabaceae and Dipterocarpaceae, both ingroups of Magnoliopsida ("angiosperms") with their own specific faunas.

Some elements of the fauna abundant during the Miocene are today abundant and associated with trees of the group Hymenaea (ingroup of Fabaceae and Magnoliopsida, "angiosperms") but absent in forests dominated by trees of the group Coniferopsida ("gymnosperms"; e.g. Peris et al., 2015, 2017a).

Some other faunal elements related to trees of the group Coniferopsida during the Cretaceous, such as pollinators, including lacewings, did not undergo an evolutionary shift to trees of the group Magnoliopsida (Peris et al., 2017b). In this regard, it is interesting that the most common forms in Miocene ambers are larvae of owlflies (nine specimens) and antlions (four specimens; additionally, three aphid-lion specimens). Owlfly(-like) and antlion larvae are quite rare in Eocene ambers, and in the case of antlions also in Cretaceous ambers. Hitherto, there is no study of differing ecological biases concentrated on larvae on resin-producing trees of the groups Magnoliopsida vs. Coniferopsida. Such an actuo-taphonomic study could test whether the abundance of lacewing larvae is related to an ecological bias. For further exploring this aspect, we will need more quantitative data from unbiased amber, copal and resin collections.

\section{Outlook}

Fossils from Cretaceous and Eocene amber have already been used for quantitatively comparing morphology of lacewing larvae through time (Haug et al., 2020a). Such studies can reveal interesting patterns for improving our understanding of the changes of lacewing diversity in particular, but also losses of diversity in general. The Miocene could potentially add another time slice to such a comparison, yet the overall low number of available lacewing larvae is partly challenging in this aspect.

It may still be a matter of focussed interest in adults that simply leads to the effect that larvae, yet being in fact present, do not surface. We hope that the present contribution can also serve to encourage more people, professional and amateur, to report on more lacewing larvae from Miocene ambers. In this way, we hope to be able to integrate these ambers into larger quantitative analyses. 


\section{Acknowledgements}

We are grateful to María de Lourdes Serrano Sánchez, Mexico City, and two anonymous reviewers for helpful comments. We thank TerraTreasures and Adventures 101 (terratreasures.com), Huang Yi-Jen (amber boy, huangyijen0708), and GlobalNaturalResources for kindly providing images. The Volkswagen Foundation kindly funds JTH with a Lichtenberg Professorship and MMSK (Project N. 90946). MMSK also thanks the Ministry of Economy and Competitiveness of Spain (project "CRE", Spanish AEI/FEDER, UE GGL2017-84419). CH and VB were funded via the LMU excellent Junior Researcher Fund. We thank J.M. Starck, Munich, for continuous support. We highly appreciate the effort of all people involved in providing open access, open source and low cost software. This is LEON publication \#18.

\section{References}

Alvarado-Ortega, J., Guevas-García, M., Cantalice, K., 2018, The fossil fishes of the archaeological site of Palenque, Chiapas, southeastern Mexico: Journal of Archaeological Science: Reports, 17, 462-476. https://doi. org/10.1016/j.jasrep.2017.11.029

Antoine, P.O., De Franceschi, D., Flynn, J.J., Nel, A., Baby, P., Benammi, M., Calderón, Y., Espurt, N., Goswami, A., Salas-Gismondi, R., 2006, Amber from western Amazonia reveals Neotropical diversity during the middle Miocene: Proceedings of the National Academy of Sciences of the United States of America, 103(37), 13595-13600. https:// doi.org/10.1073/pnas.0605801103

Arillo, A., Ortuño, V.M., 2005, Catalogue of fossil insect species described from Dominican amber (Miocene): Stuttgarter Beiträge zur Naturkunde-Serie B (Geologie und Paläontologie), 352, 1-68.

Aspöck, U., Aspöck, H., 1999, Kamelhälse, Schlammfliegen, Ameisenlöwen. Wer sind sie?(Insecta: Neuropterida: Raphidioptera,
Megaloptera, Neuroptera): Stapfia, 60(138), $1-34$.

Aspöck, U., Aspöck, H., 2007, Verbliebene Vielfalt vergangener Blüte. Zur Evolution, Phylogenie und Biodiversität der Neuropterida:(Insecta: Endopterygota): Denisia 20, Kataloge der Oberöstereichischen Landesmuseen Neue Serie, 66, 451-516.

Aspöck, U., Aspöck, H., 2010, Erobern Nevrorthidae Mitteleuropa? Eine biogeographische Provokation (Neuroptera: Neuropterida): Denisia, 29, 25-35.

Badano, D., 2012, The larvae of European Myrmeleontidae and Ascalaphidae (Neuroptera): Sassari, Università degli Studi di Sassari, PhD dissertation.

Badano, D., Aspöck, U., Aspöck, H., Cerretti, P., 2017, Phylogeny of Myrmeleontiformia based on larval morphology (Neuropterida: Neuroptera): Systematic Entomology, 42(1), 94-117. https://doi.org/10.1111/ syen. 12200

Badano, D., Engel, M.S., Basso, A., Wang, B., Cerretti, P., 2018, Diverse Cretaceous larvae reveal the evolutionary and behavioural history of antlions and lacewings: Nature Communications, 9(1), 3257. https://doi. org/10.1038/s41467-018-05484-y

Bouju, V., Perrichot, V., 2020, A review of amber and copal occurrences in Africa and their paleontological significance: BSGF - Earth Sciences Bulletin, 191(1), 17. https://doi. org/10.1051/bsgf/2020018

Calvillo-Canadell, L., Cevallos-Ferriz, S.R., Rico-Arce, L., 2010, Miocene Hymenaea flowers preserved in amber from Simojovel de Allende, Chiapas, Mexico: Review of Palaeobotany and Palynology, 160(3-4), 126-134. https://doi.org/10.1016/j. revpalbo.2010.02.007

Dayvault, R.D., Codington, L.A., Kohls, D., Hawes, W.D., Ott, P.M., Behnke, D., 1995, Fossil insects and spiders from three locations in the Green River Formation of the Piceance Creek Basin, Colorado, in Averett, W.R. (ed.), The Green River Formation in 
Piceance Creek and Eastern Uinta Basins: Grand Junction, Golorado, Grand Junction Geological Society, 97-116.

Engel, M.S., 2004, The dustywings in Cretaceous Burmese amber (Insecta: Neuroptera: Coniopterygidae): Journal of Systematic Palaeontology, 2(2), 133-136. https://doi. org/10.1017/S1477201904001191

Engel, M.S., Grimaldi, D.A., 2007, The Neuropterid Fauna of Dominican and Mexican Amber (Neuropterida: Megaloptera, Neuroptera): American Museum Novitates, 3587, 1-58. https://doi.org/10.1206/0003$0082(2007) 3587$ [1: T N F O D ] 2.0. $\mathrm{CO} ; 2$

Engel, M.S., Grimaldi, D.A., 2008, Diverse Neuropterida in Cretaceous amber, with particular reference to the paleofauna of Myanmar (Insecta): Nova Supplementa Entomologica, Keltern, 20, 1-86.

Gepp, J., 1984, Erforschungsstand der Neuropteren. Larven der Erde (mit einem Schlüssel zur Larvaldiagnose der Familien, einer Übersicht von 340 beschriebenen Larven und 600 Literaturzitaten), in Progress in World's Neuropterology: Graz, Proceedings of the First International Symposium on Neuropterology, 183-239.

Grimaldi, D.A., 2000, A diverse fauna of Neuropterodea in amber from the Cretaceous of New Jersey, in Studies on fossil in amber, with particular reference to the Cretaceous of New Jersey: Leiden, Backhuys Publishers, 259-303.

Grimaldi, D., Engel, M.S., 2005, Evolution of the

Insects: Cambridge, Cambridge University Press, 755 p.

Grimaldi, D., Engel, M.S., Singh, H., 2013, Coniopterygidae (Neuroptera: Aleuropteryginae) in amber from the Eocene of India and the Miocene of Hispaniola: American Museum Novitates, 2013(3770), 2039. https://doi.org/10.1206/3770.2

Gröhn, C., 2015, Einschlüsse im baltischen Bernstein: Kiel, Verlag Wachholtz, 424 p.

Grund, M., 2006, Chironomidae (Diptera) in Dominican amber as indicators for ecosystem stability in the Caribbean: Palaeogeography, Palaeoclimatology, Palaeoecology, 241(34), 410-416. https://doi.org/10.1016/j. palaeo.2006.04.005

Haug, G., Shannon, K.R., Nyborg, T., Vega, FJ., 2013b, Isolated mantis shrimp dactyli from the Pliocene of North Carolina and their bearing on the history of Stomatopoda: Bolétin de la Sociedad Geológica Mexicana, 65, 273-284. http://dx.doi.org/10.18268/ BSGM2013v65n2a9

Haug, G., Herrera-Flórez, A.F., Müller, P., Haug, J.T., 2019c, Cretaceous chimera-an unusual 100-million-year old neuropteran larva from the "experimental phase" of insect evolution: Palaeodiversity, 12(1), 1-11. https://doi.org/10.18476/pale.v12. al

Haug, G.T., Haug, C., Pazinato, P.G., Braig, F., Perrichot, V., Gröhn, C., Müller, P., Haug, J.T., 2020a, The decline of silky lacewings and morphological diversity of long-nosed antlion larvae through time: Palaeontologia Electronica, 23(2), a39. https://doi. org/10.26879/1029

Haug, J.T., 2020, Why the term "larva" is ambiguous, or what makes a larva?: Acta Zoologica, 101, 167-188. https://doi. org/10.1111/azo.12283

Haug, J.T., Haug, C., 2019, Beetle larvae with unusually large terminal ends and a fossil that beats them all (Scraptiidae, Coleoptera): PeerJ, 7, e7871. https://doi.org/10.7717/ peerj.7871

Haug, J.T., Haug, G., Ehrlich, M., 2008, First fossil stomatopod larva (Arthropoda: Crustacea) and a new way of documenting Solnhofen fossils (Upper Jurassic, Southern Germany): Palaeodiversity, 1, 103-109.

Haug, J.T., Haug, C., Kutschera, V., Mayer, G., Maas, A., Liebau, S., Castellani, C., Wolfram, U., Clarkson, E.N.K., Waloszek, D., 2011, Autofluorescence imaging, an excellent tool for comparative morphology: Journal of Microscopy, 244, 259-272. https://doi. org/10.1111/j.1365-2818.2011.03534.x 
Haug, J.T., Müller, G.H.G., Sombke, A., 2013a, A centipede nymph in Baltic amber and a new approach to document amber fossils: Organisms Diversity and Evolution, 13, 425-432. https://doi.org/10.1007/ s13127-013-0129-3

Haug, J.T., Müller, P., Haug, C., 2018, The ride of the parasite: a 100-million-year old mantis lacewing larva captured while mounting its spider host: Zoological Letters, 4(31), 1-8. https://doi.org/10.1186/s40851-018-0116-9

Haug, J.T., Müller, P., Haug, C., 2019a, A 100-million-year old predator: a fossil neuropteran larva with unusually elongated mouthparts: Zoological Letters, 5(1), 1-14. https://doi.org/10.1186/s40851-019-0144-0

Haug, J.T., Müller, P., Haug, C., 2019b, A 100-million-year old slim insectan predator with massive venom-injecting stylets - a new type of neuropteran larva from Burmese amber: Bulletin of Geosciences, 94, 431-440. https://doi.org/10.3140/bull.geosci.1753

Haug, J.T., Azar, D., Ross, A., Szwedo, J., Wang, Bo, Arillo, A., Baranov, V., Bechteler, J., Beutel, R., Blagoderov, V., Delclòs, X., Dunlop, J., Feldberg, K., Feldmann, R., Foth, G., Fraaije, R.H.B., Gehler, A., Harms, D., Hedenäs, L., Hyžny, M., Jagt, J.W.M., Jagt-Yazykova, E.A., Jarzembowski, E., Kerp, H., Khine, P.K., Kirejtshuk, A.G., Klug, C., Kopylov, D.S., Kotthoff, U., Kriwet, J., McKellar, R.G., Nel, A., Neumann, G., Nützel, A., Peñalver, E., Perrichot, V., Pint, A., Ragazzi, E., Regalado, L., Reich, M., Rikkinen, J., Sadowski, E.-M., Schmidt, A.R., Schneider, H., Schram, F.R., Schweigert, G., Selden, P., Seyfullah, L.J., Solórzano-Kraemer, M.M., Stilwell, J.D., van Bakel, B.W.M., Vega, FJ., Wang, Yongdong, Xing, Lida, Haug, C., 2020c, Comment on the letter of the Society of Vertebrate Paleontology (SVP) dated April 21, 2020 regarding "Fossils from conflict zones and reproducibility of fossil-based scientific data": Myanmar amber: PalZ, 94, 431-437. https:/ / doi.org/10.1007/s12542-020-00524-9

Haug, J.T., Baranov, V., Schädel, M., Müller, P.,
Gröhn, P., Haug, C., 2020b, Challenges for understanding lacewings: how to deal with the incomplete data from extant and fossil larvae of Nevrorthidae? (Neuroptera): Fragmenta Entomologica, 52, 137-167. https://doi. org/10.4081/fe.2020.472

Herrera-Flórez, A.F., Braig, F., Haug, C., Neumann, G., Wunderlich, J., Hörnig, M.K., Haug, J.T., 2020, Identifying the oldest larva of a myrmeleontiformian lacewing - a morphometric approach: Acta Palaeontologica Polonica, 65, 235-250. https://doi.org/10.4202/app.00662.2019

Iturralde-Vinent, M.A., MacPhee, R.D.E., 1996, Age and paleogeographical origin of Dominican amber: Science, 273(5283), 1850-1852. https://doi.org/10.1126/ science.273.5283.1850

Iturralde-Vinent, M.A., MacPhee, R.D., 2019, Remarks on the age of Dominican amber: Palaeoentomology, 2, 236-240. https://doi. org/10.11646/palaeoentomology.2.3.7

Janzen, J.W., 2002, Arthropods in Baltic Amber: Ampyx Verlag, Halle, 167 p.

Kobbert, M.J., 2013, Wunderwelt Bernstein: Faszinierende Fossilien in 3-D: WBG (Wissenschaftliche Buchgesellschaft), Darmstadt.

Larsson, S.G., 1978, Baltic Amber: a Palaeobiological Study: Scandinavian Science Press, Klampenborg, Denmark.

Liu, X., Zhang, W., Winterton, S.L., Breitkreuz, L.C., Engel, M.S., 2016, Early morphological specialization for insect-spider associations in Mesozoic lacewings: Current Biology, 26, 1590-1594. https://doi.org/10.1016/j. cub.2016.04.039

Liu, X., Shi, G., Xia, F., Lu, X., Wang, B., Engel, M.S., 2018, Liverwort mimesis in a Cretaceous lacewing larva: Current Biology, 28, 1475-1481. https://doi.org/10.1016/j. cub.2018.03.060

Lu, X., Xia, F., Wang, B., Aspöck, U., Liu, X., 2018, Taxonomic notes on Cretarophalis patrickmuelleri Wichard, 2017 (Insecta: Neuroptera: Nevrorthidae) from the mid-Cretaceous of 
Myanmar, and its phylogenetic significance: Zootaxa, 4370, 591-600. https://doi.org/ 10.11646/zootaxa.4370.5.10

MacLeod, E.G., 1964, A comparative morphological study of the head capsule and cervix of larval Neuroptera (Insecta): Cambridge, U.S.A., Harvard University, $\mathrm{PhD}$ dissertation.

MacLeod, E.G., 1970, The Neuroptera of the Baltic Amber. I. Ascalaphidae, Nymphidae, and Psychopsidae: Psyche: A Journal of Entomology, 77, 147-180. https://doi. org/10.1155/1970/45459

Makarkin, V.N., 2018, Re-description of Grammapsychops lebedevi Martynova, 1954 (Neuroptera: Psychopsidae) with notes on the Late Cretaceous psychopsoids: Zootaxa, 4524, 581-594. https://doi.org/10.11646/ zootaxa.4524.5.5

Makarkin, V.N., Wedmann, S., Weiterschan, T., 2012, First record of a fossil larva of Hemerobiidae (Neuroptera) from Baltic amber: Zootaxa, 3417(2), 53-63. https:// doi.org/10.11646/zootaxa.3417.1.3

Martins-Neto, R.G., Heads, S.W., Bechly G., 2007, Neuropterida: snakeflies, dobsonflies and lacewings, in Martill, D., Bechly, G., Loveridge, R. (eds.), The Crato Fossil Beds of Brazil: Window into an Ancient World: Cambridge, Cambridge University Press, 328-340.

Ohl, M., 2011, Aboard a spider - a complex developmental strategy fossilized in amber: Naturwissenschaften, 98, 453. https://doi. org/10.1007/s00114-011-0783-2

Peng, Y., Makarkin, V.N., Wang, X., Ren, D., 2011, A new fossil silky lacewing genus (Neuroptera, Psychopsidae) from the Early Cretaceous Yixian Formation of China: ZooKeys, 130, 217-228. https://doi. org/10.3897/zookeys. 130.1576

Penney, D., 2016, Amber Palaeobiology: Research trends and perspectives for the 21st century. Rochdale, UK, Siri Scientific Press.

Pérez-de la Fuente, R., Delclòs, X., Peñalver, E., Speranza, M., Wierzchos, J., Ascaso,
C., Engel, M.S., 2012, Early evolution and ecology of camouflage in insects: Proceedings of the National Academy of Sciences of the United States of America, 109, 21414-21419. https://doi.org/10.1073/pnas.1213775110

Pérez-de la Fuente, R., Delclos, X., Penalver, E., Engel, M.S., 2016, A defensive behavior and plant-insect interaction in Early Cretaceous amber-the case of the immature lacewing Hallucinochrysa diogenesi: Arthropod Structure and Development, 45, 133-139. https://doi. org/10.1016/j.asd.2015.08.002

Pérez-de la Fuente, R., Peñalver, E., Azar, D., Engel, M.S., 2018, A soil-carrying lacewing larva in Early Cretaceous Lebanese amber: Scientific Reports, 8, 16663. https://doi. org/10.1038/s41598-018-34870-1

Pérez-de la Fuente, R., Engel, M.S., Azar, D., Peñalver, E., 2019, The hatching mechanism of 130-million-year-old insects: an association of neonates, egg shells and egg bursters in Lebanese amber: Palaeontology, 62, 547559. https://doi.org/10.1111/pala.12414

Pérez-de la Fuente, R., Engel, M.S., Delclòs, X., Peñalver, E., 2020, Straight-jawed lacewing larvae (Neuroptera) from Lower Cretaceous Spanish amber, with an account on the known amber diversity of neuropterid immatures: Cretaceous Research, 106, 104200. https:// doi.org/10.1016/j.cretres.2019.104200

Peris, D., Solórzano-Kraemer, M.M., Peñalver, E., Delclòs, X., 2015, New ambrosia beetles (Coleoptera: Curculionidae: Platypodinae) from Miocene Mexican and Dominican ambers and their paleobiogeographical implications: Organisms Diversity and Evolution, 15, 527-542. https://doi. org/10.1007/s13127-015-0213-y

Peris, D., Solórzano-Kraemer, M.M., Smith, S.M., Cognato, A.I., 2017a, Eoplatypus jordali gen. n. et sp. n., the first described Platypodinae (Coleoptera: Curculionidae) from Baltic amber: Arthropod Systematics and Phylogeny, 75, 185-194.

Peris, D., Pérez-de la Fuente, R., Peñalver, E., Delclòs, X., Barrón, E., Labandeira, 
C.C., 2017b, False blister beetles and the expansion of gymnosperm-insect pollination modes before angiosperm dominance: Current Biology, 27, 897-904. https://doi. org/10.1016/j.cub.2017.02.009

Perrichot, V., 2003, Environnements paraliques à ambre et à végétaux du Crétacé nord-aquitain (Charentes, Sud-Ouest de la France): Rennes, Université Rennes 1, PhD dissertation.

Perrichot, V., Neraudeau, D., Tafforeau, P., 2010, Charentese amber, in Penney, D. (ed.), Biodiversity of fossils in amber from the major world deposits: Manchester, UK, Siri Scientific Press, 192-207.

Poinar Jr., G., 1991, Hymenaea protera sp.n. (Leguminosae, Caesalpinioideae) from Dominican amber has African affinities: Experientia, 47, 1075-1082. https://doi. org/10.1007/BF01923347

Poinar Jr., G., Brown, A.E., 2002, Hymenaea mexicana sp. nov.(Leguminosae: Caesalpinioideae) from Mexican amber indicates Old World connections: Botanical Journal of the Linnean Society, 139, 125-132. https://doi. org/10.1046/j.1095-8339.2002.00053.x

Poinar Jr., G.O., Poinar R., 1999, The Amber Forest: Princeton, Princeton University Press.

Scheven, J., 2004, Bernstein-Einschlüsse: Eine untergegangene Welt bezeugt die Schöpfung. Erinnerungen an die Welt vor der Sintflut: Hofheim a.T., Kuratorium Lebendige Vorwelt.

Schmidt, A.R., Jancke, S., Lindquist, E.E., Ragazzi, E., Roghi, G., Nascimbene, P.C., Schmidt, K., Wappler, T., Grimaldi, D.A., 2012, Arthropods in amber from the Triassic Period: Proceedings of the National Academy of Sciences, 109, 14796-14801. https://doi. org/10.1073/pnas. 1208464109

Schmidt, A.R., Kaulfuss, U., Bannister, J.M., Baranov, V., Beimforde, C., Bleile, N., Borkent, A., Busch, A., Conran, J.G., Engel, M.S., Harvey, M., Kennedy, E.M., Kerr, P., Kettunen, E., Philie Kiecksee, A., Lengeling, F., Lindqvist, J.K., Maraun, M., Mildenhall,
D.C., Perrichot, V., Rikkinen, J., Sadowski, E.-M., Seyfullah, L.J., Stebner, F., Szwedo, J., Ulbrich, P., Lee, D.E., 2018, Amber inclusions from New Zealand: Gondwana Research, 56, 135-146. https://doi.org/10.1016/j. gr.2017.12.003

Serrano-Sánchez, M., Hegna, T.A., Schaaf, P., Pérez, L., Centeno-García, E., Vega, F.J., 2015, The aquatic and semiaquatic biota in Miocene amber from the Campo La Granja mine (Chiapas, Mexico): Paleoenvironmental implications: Journal of South American Earth Sciences, 62, 243-256. https://doi. org/10.1016/j.jsames.2015.06.007

Seyfullah, L.J., Beimforde, C., Dal Corso, J., Perrichot, V., Rikkinen, J., Schmidt, A.R., 2018, Production and preservation of resins-past and present: Biological Reviews, 93, 1684-1714. https://doi.org/10.1111/ brv. 12414

Shi, G., Dutta, S., Paul, S., Wang, B., Jacques, F.M.B., 2014, Terpenoid compositions and botanical origins of Late Cretaceous and Miocene amber from China: PLoS ONE, 9, e111303. https://doi.org/10.1371/journal. pone.0111303

Solórzano-Kraemer, M.M., 2007, Systematic, palaeoecology, and palaeobiogeography of the insect fauna from Mexican amber: Palaeontographica Abteilung A, 282, 1-133. https://doi.org/10.1127/pala/282/2007/1

Solórzano-Kraemer,M.M., Delclòs, X., Engel, M.S. Peñalver, E., 2020, A revised definition for copal and its significance for palaeontological and Anthropocene biodiversity-loss studies: Scientific Reports, 10, 19904. https://doi.org/10.1038/ s41598-020-76808-6

Solórzano-Kraemer, M.M., Kraemer, A.S., Stebner, F., Bickel, D.J., Rust, J., 2015, Entrapment bias of arthropods in Miocene amber revealed by trapping experiments in a tropical forest in Chiapas, Mexico: PLoS ONE, 10, e0126046. https://doi. org/10.1371/journal.pone.0118820 
Solórzano-Kraemer, M.M., Delclòs, X., Clapham, M.E., Arillo, A., Peris, D., Jäger, P., Stebner, F., Peñalver, E., 2018, Arthropods in modern resins reveal if amber accurately recorded forest arthropod communities: Proceedings of the National Academy of Sciences, 115, 6739-6744. https://doi.org/10.1073/ pnas. 1802138115

Tauber, M.J., Tauber, C.A., Daane, K.M., Hagen, K.S., 2000, Commercialization of predators: recent lessons from green lacewings (Neuroptera: Chrysopidae: Chrysoperla): American Entomologist, 46, 26-38. https:// doi.org/10.1093/ae/46.1.26

Tauber, G.A., Tauber, M.J., Albuquerque, G.S., 2003, Neuroptera (lacewings, antlions), in Resh, V.H., Cardé, R.T., (eds.), Encyclopedia of insects: San Diego, London, Burlington, Academic Press, 695-707.

Wang, B., Xia, F., Engel, M.S., Perrichot, V., Shi, G., Zhang, H., Chen, J., Jarzembowski, E.A., Wappler, T., Rust, J., 2016, Debriscarrying camouflage among diverse lineages of Cretaceous insects: Science Advances, 2, e1501918. https://doi.org/10.1126/ sciadv. 1501918

Wedmann, S., Makarkin, V.N., Weiterschan, T., Hörnschemeyer, T., 2013, First fossil larvae of Berothidae (Neuroptera) from Baltic amber, with notes on the biology and termitophily of the family: Zootaxa, 3716, 236-258. https:// doi.org/10.11646/zootaxa.3716.2.6

Weidner, H., 1958, Einige interessante Insektenlarven aus der BemsteininklusenSammlung des Geologischen Staatsinstituts Hamburg (Odonata, Coleoptera, Megaloptera, Planipennia): Mitteilungen aus dem Geologisch-Paläontologischen Institut (GPI) der Universität Hamburg, 27, 50-68.

Weitschat, W., 2009, Jäger, Gejagte, Parasiten und Bilnde Passagiere - Momentaufnahmen aus dem Bernsteinwald: Denisia, 26, zugleich Kataloge der oberöstereichischen Landesmuseen Neue Serie, 86, 243-256.

Weitschat, W., Wichard, W., 1998, Atlas der
Tiere und Pflanzen im Baltischen Bernstein: München, Dr. Friedrich Pfeil.

Weitschat, W., Wichard, W., 2002, Atlas of Plants and Animals in Baltic Amber: München, Dr. Friedrich Pfeil. https://doi.org/10.1016/ s0034-6667(02)00225-7

Wichard, W., 2017, Family Nevrorthidae (Insecta, Neuroptera) in mid-Cretaceous Burmese amber: Palaeodiversity, 10, 1-6. https://doi. org/10.18476/pale.v10.al

Wichard, W., Gröhn, C., Seredszus, F., 2009, Aquatic Insects in Baltic Amber: Remagen, Kessel, 336 p.

Whalley, P.E.S., 1980, Neuroptera (Insecta) in amber from the Lower Cretaceous of Lebanon: Bulletin of the British Museum of Natural History (Geology), 33, 157-164.

Wolfe, A.P., McKellar, R.C., Tappert, R., Sodhi, R.N., Muehlenbachs, K., 2016, Bitterfeld amber is not Baltic amber: Three geochemical tests and further constraints on the botanical affinities of succinite: Review of Palaeobotany and Palynology, 225, 21-32. https://doi. org/10.1016/j.revpalbo.2015.11.002

Wu, R.J.G., 1996, Secrets of a Lost World, Dominican Amber and its Inclusions: Santo Domingo, Self published, $222 \mathrm{p}$.

Wunderlich,J., 2012, Frozen behaviour in vampires of spiders - fossil insect larvae of the family Mantispidae (Neuroptera) as parasites of sac spiders (Araneae: Clubionidae) in Eocene Baltic amber: Beiträge zur Araneologie, 7, 150-156.

Xia, F., Yang, G., Zhang, Q., Shi, G., Wang, B., 2015, Amber: Lives through Time and Space: Beijing, Science Press.

Zhang, W.W., 2017, Frozen Dimensions. The Fossil Insects and other Invertebrates in Amber: Chongqing, Chongqing University Press.

Zherikhin, V.V., Sukacheva, I.D., Rasnitsyn, A.P., 2009, Arthropods in contemporary and some fossil resins: Paleontological Journal, 43, 987-1005. https://doi.org/10.1134/ S0031030109090019

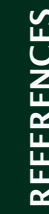

